\title{
Profit Analysis by Soil Carbon Sequestration with Different Composts and Cooperated with Biochar during Corn (Zea mays) Cultivation Periods in Sandy Loam Soil
}

\author{
Joung Du Shin ${ }^{*}$, Yong-Su Choi ${ }^{1}$, Jae-Hoon Shin ${ }^{2}$ \\ ${ }^{1}$ Department of Climate Change \& Ecology, National Institute of Agricultural Science, RDA, Wanju, Korea \\ ${ }^{2}$ Organic Agricultural Division, National Institute of Agricultural Sciences, Korea \\ Email: ${ }^{j}$ dshin1@korea.kr
}

Received 2 June 2016; accepted 1 July 2016; published 29 July 2016

Copyright (C) 2016 by authors and Scientific Research Publishing Inc.

This work is licensed under the Creative Commons Attribution International License (CC BY). http://creativecommons.org/licenses/by/4.0/

c) (†) Open Access

\section{Abstract}

Despite the ability of biochar to enhance soil fertility and to sequester soil carbon, its potential reduction of green house gas emissions and profit analysis with different organic composts and cooperated with biochar for crop cultivation have been a few evaluated. This study was conducted to estimate their greenhouse gas emission reduction and profit analysis by soil carbon sequestration with different organic composts and cooperated with biochar application during corn cultivation periods. For the experiment, the treatments were consisted of aerobic digestate of swine wastes (AD), pig compost as the control (PC), cow compost (CC) and pig compost cooperated with $1 \%$ biochar (PC + 1\% biochar). The soil texture used in this study was sandy loam, and application rates of chemical fertilizer were 190-39-221 kg.ha-1 $\left(\mathrm{N}-\mathrm{P}_{2} \mathrm{O}_{5}-\mathrm{K}_{2} \mathrm{O}\right)$ as recommended amount after soil test. The soil samples were periodically taken at every 15 day intervals during the experimental periods. It was observed that soil carbon sequestration by $A D, C C$ and $P C+1 \%$ biochar application was estimated to be $429 \mathrm{~kg} \cdot \mathrm{ha}^{-1}, 2366 \mathrm{~kg} \cdot \mathrm{ha}^{-1}$, and $3978 \mathrm{~kg} \cdot \mathrm{ha}^{-1}$, and their $\mathrm{CO}_{2}-e$ emission reductions were estimated to be 0.16 tones for $\mathrm{AD}, 0.87$ tones for $\mathrm{CC}$, and 14.58 tones for $\mathrm{PC}+$ $1 \%$ biochar per hectar for corn cultivation periods. Their profits were estimated at $\$ 14.58$ for lowest and $\$ 451.90$ for highest. In Korea Climate Exchange, it was estimated to be $\$ 115.20$ per hectar of corn cultivation with $\mathrm{PC}+1 \%$ biochar. So, the price of $\mathrm{CO}_{2}$ per hectar for corn cultivation with $\mathrm{PC}+1 \%$ biochar was high at 16.8 times relative to cow compost treatment only. For the plant growth response, it was observed that plant height and fresh ear yield were not significantly different among the treatments. Therefore, these experimental results might be fundamental data for assuming a carbon trading mechanism exists for biochar soil application in agricultural practices.

\footnotetext{
${ }^{*}$ Corresponding author.
} 


\section{Keywords}

\section{Biochar, Greenhouse Gas Emission Mitigation, Soil Carbon Sequestration, Compost}

\section{Introduction}

Global warming is becoming a critical issue around the world. Numerous researchers and organizations have been involved in reducing the greenhouse gases from various sources [1]-[3]. Since many countries recognized the importance of greenhouse gases (GHG), including methane $\left(\mathrm{CH}_{4}\right)$, carbon dioxide $\left(\mathrm{CO}_{2}\right)$, and nitrous oxide $\left(\mathrm{N}_{2} \mathrm{O}\right)$, the estimation of GHG emission was conducted for a comprehensive understanding of the effect of GHG in each country in terms of global warming and the significant mitigation potential [2] [4]-[6]. Biomass is composed of carbon rich materials including all plants, animals, nutrients, excrements and bio-waste from households and industries [7]. Unused or discarded biomass residues from agricultural areas are potential energy resource, but at same time can be a source of GHG emissions, causing a significant environmental problem. Potential energy production from crop and animal residues is globally estimated to be about $34 \mathrm{EJ}$ (exajoule $=10^{18}$ joules) out of a total $70 \mathrm{EJ}$ [8]. In Korea, it is estimated that over 50 million tones of organic wastes are produced every year in agricultural sector out of over 80 million tones [9]. The interest of biomass in resource-poor country such as Korea is therefore increasing.

Biochar is the carbonaceous product obtained by heat treatment of biomass under limited or no oxygen (pyrolysis or liquefaction technology). Biochar has recently gained attention for its potential, when cooperated with soil to improve soil fertility and to store carbon removed from the atmosphere by plants. Biochar's positive effects on the soil ecosystem, including both plants and microbes, have been proposed to derive either directly from nutrients within biochar itself or indirectly its ability to absorb and retain nutrients [10]-[12].

Soil plays significant roles in global carbon cycle. It is estimated that soils have contributed as much as 55 to 878 billion tones (GT) of carbon to the total atmospheric $\mathrm{CO}_{2}$ [13]. The total soil carbon consists of the soil organic and inorganic carbons, estimated to be approximately over 2250 GT in the top 1 meter depth [14]. While the soil organic carbon contributes approximately $25 \%$ of overall soil carbon inventory, agricultural practices have more propound influence on the change of soil organic carbon both in the short and the long term. Thus carbon sequestration in soils, i.e., increasing soil organic carbon through proper management of biochar input, provides a multitude of environmental benefits. For estimating the value of potential $\mathrm{CO}_{2}$ offset, a low and high value of $\$ 1$ and $\$ 31 \mathrm{MT} \mathrm{CO}_{2}$ is used [15] [16], assuming a carbon trading mechanism exists for biochar application in the agricultural practices.

Regarding the effect of biochar application, when biochar from rice hulls is cooperated with soil $(0.2 \%$ of soil weight), applications of aerobic swine digestate, cow compost, and pig compost can sequester $\mathrm{C}$ by $38.9 \%, 82.2 \%$ and $19.7 \%$ in soil, respectively [17]. For the profit analysis, it is reported that the market price of $\mathrm{CO}_{2}$ in corn cultivation with $0.2 \%, 1 \%$ and $2 \%$ biochar application is \$35.6, \$115.3 and \$428.2 per hectar in Korea Climate Exchange (KCX), respectively [18].

Therefore, this study was conducted to estimate their carbon sequestration, potential reduction of greenhouse gas emission and profit analysis with different organic composts and cooperated with biochar application during corn cultivation periods.

\section{Materials and Methods}

The corn variety used in this experiment was Miback 2 Ho those kernel is white and sticky, and planting distance was $30 \times 60 \mathrm{~cm}$. Corn cultivation was based on crop guideline from Rural Development Administration (RDA). Soil texture was sandy loam. The experimental design of this study was a randomized split plot design with three replications. The treatments were consisted of cow compost (CC), pig compost (PC), aerobic digestate (AD) of swine waste, and biochar cooperation. Fertilizers were applied with 190-39-221 kg.ha ${ }^{-1}$ $\left(\mathrm{N}-\mathrm{P}_{2} \mathrm{O}_{5}-\mathrm{K}_{2} \mathrm{O}\right.$ ) as whole basal application for $\mathrm{P}_{2} \mathrm{O}_{5}$ and $\mathrm{K}_{2} \mathrm{O}$, and it was especially applied half for basal at 3 day before sowing and half for additional application for nitrogen, based on chemical properties of soil before experiment. PC and CC were applied with 25,000 and $5500 \mathrm{~kg} \cdot \mathrm{ha}^{-1}$ into soil, recommended application rates based on chemical properties before experiment, respectively. AD was applied with 100 ton $^{-1}{ }^{-1}$ in soil that was $16 \%$ 
of water holding capacity. Application rate of biochar cooperated with soil was $1 \%$ of soil weight $(1,300,000$ $\mathrm{kg} \cdot \mathrm{ha}^{-1}$ ) [18]. Biochar from rice hull was purchased from local farming cooperative society. Chemical properties of soil used were presented in Table 1.

Soil samples were periodically collected for 15 days after treatment during corn cultivation periods. The samples were dried and passed through $2 \mathrm{~mm}$ sieve and then stored in refrigerator $\left(4^{\circ} \mathrm{C}\right)$ until analyzing the soil chemical properties.

Analytical soil chemical properties were total nitrogen (TN), total carbon (TC), total organic carbon (TOC) and total inorganic carbon (TIC) by TOC analyzer (Elementar Vario EL II, Germany). Total carbon combustion temperature was $950^{\circ} \mathrm{C}$ and $\mathrm{WO}_{3}$ was used as the catalyst. The carbonate was destroyed completely by using 2 $\mathrm{M} \mathrm{HCl}$ until there were no bubbles and fumes, and then samples were dried for another analysis. Consequently, TOC content was obtained. Total inorganic carbon (TIC) was determined by the difference between TC and TOC.

The soil carbon sequestration by biochar application is determined by the soil carbon residual differences between compost treatments only and cooperated with biochar after harvesting corn. The following equation was used:

$$
\mathrm{SS}_{\mathrm{TC}}=\left(\mathrm{T}_{\mathrm{TC}} i-\mathrm{NT}_{\mathrm{TC}} i\right) * \mathrm{SW}
$$

$\mathrm{SS}_{\mathrm{TC}}=$ Sequestration of soil carbon $\left(\mathrm{kg} \cdot \mathrm{ha}^{-1}\right)$.

$\mathrm{T}=$ Treatment of organic composts and cooperated with biochar.

$\mathrm{NT}=$ Non-treatment of pig composts only.

$i$ = Date of last measurement of soil carbon analyzed.

SW $=$ Soil weight $\left(\mathrm{kg} \cdot \mathrm{ha}^{-1}\right)$.

The reduction of greenhouse gas emissions was estimated by using Equation (2) as follow:

$$
\mathrm{CO}_{2}-\mathrm{e}=\mathrm{SS}_{\mathrm{TC}} \times \mathrm{CF}_{\mathrm{sc}}
$$

$\mathrm{SS}_{\mathrm{TC}}=$ Sequestration of soil carbon $\left(\mathrm{kg} \cdot \mathrm{ha}^{-1}\right)$.

$\mathrm{CF}_{\mathrm{sc}}=$ Conversion factor of $\mathrm{CO}_{2}$ emission from soil carbon.

\section{Results and Discussions}

\subsection{Chemical Properties of Input Materials}

For investigating TC contents of input materials, its biochar was higher at 2.1 times than PC. Biochar could be mostly organic carbon as well as its PC due to carbon fractions (Table 2). However, biochar could be mostly non-degradable organic carbon on the contrary of its PC because it resists microbial decomposition in the soil for a much longer time than regular biomass [11]. Additionally, biochar's carbon bonds can't be broken down, and remain in soil for centuries [19]. Lowest TC content was observed to be its CC. For nitrogen contents of input materials, TN content of PC was highest at 1.5\% (Table 2). Furthermore, TC contents of biochar were increased at $19.7 \%$ and 1.5 times when compared with original material, rice hull.

Table 1. Physiochemical properties of soil used in this study.

\begin{tabular}{ccccccccc}
\hline Soil type & $\begin{array}{c}\mathrm{pH} \\
(1: 5)\end{array}$ & $\begin{array}{c}\mathrm{EC} \\
(\mathrm{dS} / \mathrm{m})\end{array}$ & $\begin{array}{c}\mathrm{T}-\mathrm{C} \\
(\mathrm{g} / \mathrm{kg})\end{array}$ & $\begin{array}{c}\mathrm{T}-\mathrm{N} \\
(\mathrm{g} / \mathrm{kg})\end{array}$ & $\begin{array}{c}\text { Av. } \mathrm{P}_{2} \mathrm{O}_{5} \\
(\mathrm{mg} / \mathrm{kg})\end{array}$ & $\mathrm{K}$ & \multicolumn{3}{c}{ Ex. Cation $\left(\mathrm{cmol}^{+} / \mathrm{kg}\right)$} \\
\hline Sandy loam & 6.2 & 3.5 & 11.8 & 5.8 & 234 & 0.15 & 4.20 & 1.11 \\
\hline
\end{tabular}

\begin{tabular}{|c|c|c|c|c|}
\hline \multirow{2}{*}{ Input materials ${ }^{*}$} & TC & TOC & TIC & $\mathrm{TN}$ \\
\hline & \multicolumn{4}{|c|}{ 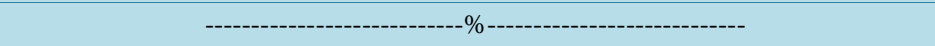 } \\
\hline CC & $27.1 \pm 0.2$ & $26.6 \pm 0.2$ & 0.33 & 1.1 \\
\hline $\mathrm{PC}$ & $41.5 \pm 0.2$ & $34.8 \pm 0.4$ & 6.7 & 1.5 \\
\hline Rice hull & $36.7 \pm 0.4$ & - & - & $0.37 \pm 0.03$ \\
\hline Biochar based rice hull & $56.4 \pm 0.1$ & $55.2 \pm 0.4$ & 1.15 & - \\
\hline
\end{tabular}

Table 2. Soil carbon fractions and total nitrogen contents of input materials.

\footnotetext{
${ }^{*} \mathrm{CC}$; cow compost, PC; pig compost.
} 


\subsection{Changes of Soil Total Carbon and Organic Carbon Contents with Different Organic Composts and Cooperated with Biochar Application}

Changes of TC and TOC contents with different organic composts and cooperated with biochar in the sandy loam soil during corn cultivation periods were described in Figure 1. Soil total carbon contents were decreased from 15 days after sowing and then maintained the stage state from 75 days after sowing periods through the harvesting periods except PC $+1 \%$ biochar application. It was decreased from 30 days after sowing through corn cultivation periods in PC $+1 \%$ biochar treatment. Soil organic matter (SOM) content is a balance between addition and decomposition rates (turnover rates). The key to sustain productivity of agricultural system is the maintenance of SOM levels and nutrient cycling. However, its PC $+1 \%$ biochar treatment could be mostly non-degradable organic carbon on the contrary of its CC because it resists microbial decomposition in the soil for a much long time. For the organic carbon contents, it was appeared to be highest in PC $+1 \%$ biochar treatment. However, it was observed that the changing patterns of organic carbon contents $(<1 \%)$ were similar to their total organic carbon contents (>1\%).

\subsection{Soil Carbon Sequestration, $\mathrm{CO}_{2}$-E Emission Reduction and Profit Analysis with Different Organic Composts and Cooperated with Biochar Application}

Soil carbon sequestration with TC for different organic composts and cooperated with biochar in the sandy loam soil during corn cultivation periods was estimated by using Equation (1) (Table 3). It was estimated that soil carbon sequestration by AD, CC and PC $+1 \%$ biochar application was estimated to be $429 \mathrm{~kg} \cdot \mathrm{ha}^{-1}, 2366 \mathrm{~kg} \cdot \mathrm{ha}^{-1}$, and $3978 \mathrm{~kg} \cdot \mathrm{ha}^{-1}$, respectively, in sandy loam soil.

In 2008, prices of traded $\mathrm{CO}_{2}$ offsets on the Chicago Climate Exchange were volatile, ranging from $\$ 1$ to $\$$ 7.40 $\mathrm{MT} \mathrm{CO}_{2}$ [15]. During the same year, the market prices of $\mathrm{CO}_{2}$ offsets in the European Climate Exchange varied between $\$ 17$ and $\$ 31 \mathrm{MT} \mathrm{CO}_{2}$ [16]. Therefore, for estimating the value of potential $\mathrm{CO}_{2}$ offset, a low and high value of \$1 and \$31 MT $\mathrm{CO}_{2}$ was used, assuming a carbon trading mechanism exists for biochar application in the agricultural practices. Furthermore, the market price $\mathrm{CO}_{2}$ in $\mathrm{KCX}$ recently traded about $\$ 7.9$ per 1 Korean Allowance Unit (KAU) on January 12, 2015. $\mathrm{CO}_{2}-e$ emission reduction was calculated by using Equation (2) based on soil carbon sequestration in the corn fields cooperated with different organic composts and biochar (Table 3). It was estimated that $\mathrm{CO}_{2}-e$ emission reductions of $\mathrm{AD}, \mathrm{CC}$ and $\mathrm{PC}+1 \%$ biochar were 0.16 MT CO $\mathrm{ha}^{-1}, 0.87 \mathrm{MT} \mathrm{CO}_{2} \mathrm{ha}^{-1}$ and $14.58 \mathrm{MT} \mathrm{CO}_{2} \mathrm{ha}^{-1}$, respectively. And profitability by each treatment was ranged from $\$ 0.16$ to $\$ 4.96$ for $\mathrm{AD}$, from $\$ 0.87$ to $\$ 26.97$ for $\mathrm{CC}$ and from $\$ 14.58$ to $\$ 451.98$ for PC + 1\% biochar per hectar during corn cultivation (Table 3). However, it was estimated that the market prices of $\mathrm{CO}_{2}$ in corn cultivation with $\mathrm{AD}$, CC and $\mathrm{PC}+1 \%$ biochar were $\$ 1.26$, $\$ 6.87$ and $\$ 115.20$ per hectar, respectively, in KCE (Table 3). It was appeared that the price of $\mathrm{CO}_{2}$ per hectar for corn cultivation with $\mathrm{PC}+1 \%$ biochar was
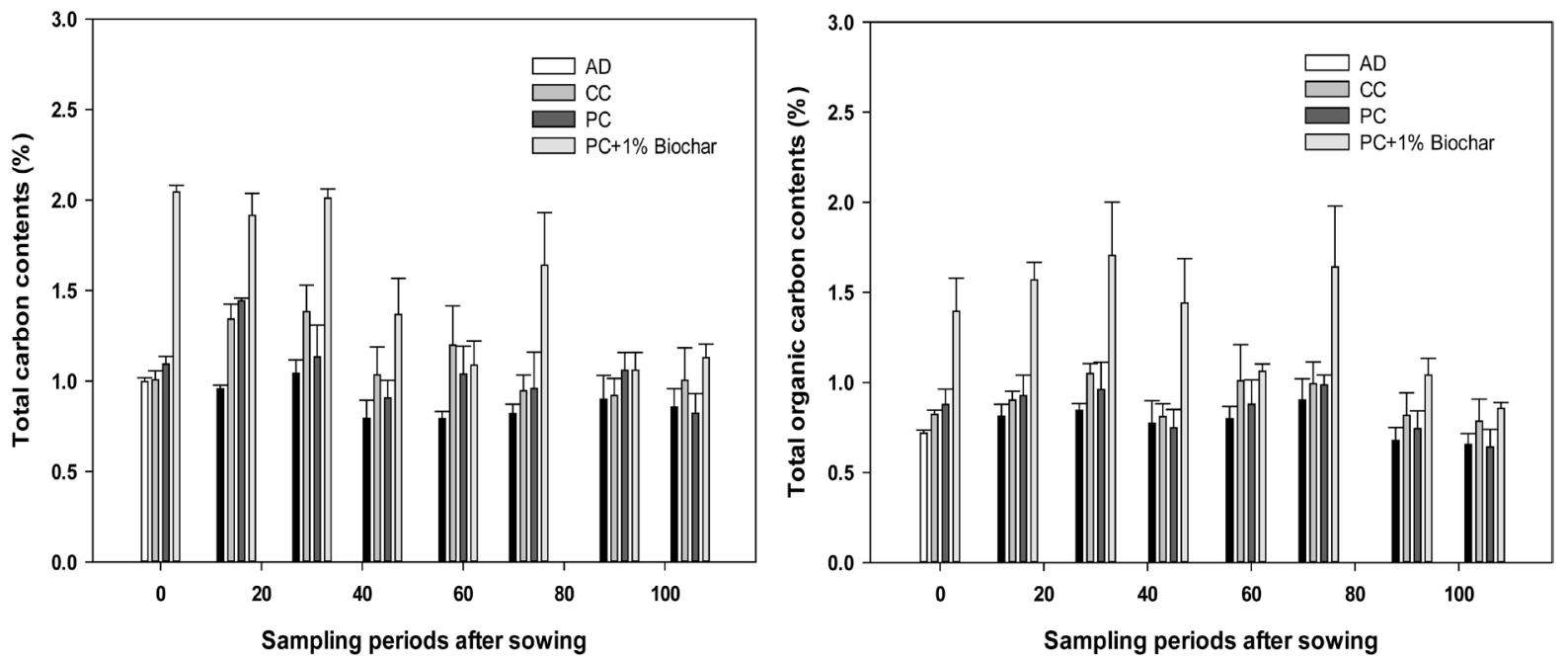

Figure 1. Changes of TC contents with different application rates of biochar in the sandy loam soil applied during corn cultivation periods (AD; aerobic digestate, CC; cow compost, PC; pig compost). 
high at 16.8 times relative to the cow compost treatment only (Table 3). It was observed that the $\mathrm{CO}_{2} \mathrm{price}$ in KCX is actually similar to $\$ 66.60 \mathrm{MT} \mathrm{ha}^{-1}$ of $0.2 \%$ biochar cooperated with CC into clay loam soil which was biannual experiment (unpublished data). Therefore, the profitability cooperated with biochar could be benefited for crop cultivation in case of carbon trading under clean mechanism development (CDM) for agricultural practices.

\subsection{Corn Growth Responses to Different Compost and Cooperated with Biochar Application}

Responses of corn growth and yield to different organic composts and cooperated with PC $+1 \%$ biochar were shown in Table 4. It was appeared that plant height and fresh yield were not significantly different among the treatments relative to the application plot of pig compost alone. It was determined that application of biochar in the corn field for carbon sequestration was significantly not occurred the damage of corn growth. Whether biochar will ultimately benefit plants by providing nutrient or inhibit plant growth by sequestering them is still an open question. Shin et al. [17] [18] reported that plant height and fresh weight were not significantly different between application plots of organic composts and plots cooperated with biochar. In the other hand, declines in plant growth in some experiments with biochar has been attributed a decline in available ammonium [19].

\section{Summary}

The quantitative analyses focus on using biochar as its carbon sequestration and greenhouse gas emission reduction benefits for agricultural uses. It was estimated that soil carbon sequestration by AD, CC and PC + 1\% biochar application was estimated to be $429 \mathrm{~kg} \cdot \mathrm{ha}^{-1}, 2366 \mathrm{~kg} \cdot \mathrm{ha}^{-1}$, and $3978 \mathrm{~kg} \cdot \mathrm{ha}^{-1}$, respectively, in sandy loam soil.

It was estimated that $\mathrm{CO}_{2}-e$ emission reductions of $\mathrm{AD}, \mathrm{CC}$ and $\mathrm{PC}+1 \%$ biochar were $0.16 \mathrm{MT} \mathrm{CO}_{2} \mathrm{ha}^{-1}$, $0.87 \mathrm{MT} \mathrm{CO}_{2} \mathrm{ha}^{-1}$ and $14.58 \mathrm{MT} \mathrm{CO}_{2} \mathrm{ha}^{-1}$, respectively. And profitability was ranged from $\$ 0.16$ to $\$ 4.96$ for $\mathrm{AD}$, from $\$ 0.87$ to $\$ 26.97$ for CC and from $\$ 14.58$ to $\$ 451.98$ for PC $+1 \%$ biochar per hectar during corn cultivation. However, it was estimated that the market prices of $\mathrm{CO}_{2}$ in corn cultivation with $\mathrm{AD}, \mathrm{CC}$ and $\mathrm{PC}+1 \%$ biochar were \$1.26, \$6.87 and \$115.20 per hectar, respectively, in KCX.

For plant responses, it was determined that application of biochar in the corn field for carbon sequestration was significantly not occurred the damage of corn growth. However, addition of biochar with organic composts could have a potential soil $\mathrm{C}$ sequestration in agricultural practices. For the future study, application of pellet form of biochar with organic compost in agricultural land need to be more elucidated soil $\mathrm{C}$ sequestration in practice with labor save and reduction of non point contaminant.

Table 3. Carbon sequestration, $\mathrm{CO}_{2}-e$ emission reduction and profit analysis with different composts and cooperated with biochar application in sandy loam soil during corn cultivation periods.

\begin{tabular}{|c|c|c|c|c|c|}
\hline \multirow{2}{*}{ Treatments ${ }^{*}$} & \multirow{2}{*}{$\begin{array}{l}\text { Carbon sequestration } \\
\qquad\left(\mathrm{kg} \cdot \mathrm{ha}^{-1}\right)^{* *}\end{array}$} & \multirow{2}{*}{$\begin{array}{l}\mathrm{CO}_{2}-e \text { emission reduction } \\
\left(\mathrm{MT} \mathrm{ha}^{-1}\right)\end{array}$} & \multicolumn{3}{|c|}{ Profit $\left(\$\right.$ ha $\left.^{-1}\right)$} \\
\hline & & & $\$ 1 / \mathrm{MT} \mathrm{CO}_{2}$ & $\$ 7.9 / \mathrm{MT} \mathrm{CO}_{2}$ & $\$ 31 / \mathrm{MT} \mathrm{CO}_{2}$ \\
\hline $\mathrm{AD}$ & 429 & 0.16 & 0.16 & 1.26 & 4.96 \\
\hline $\mathrm{CC}$ & 2,366 & 0.87 & 0.87 & 6.87 & 26.97 \\
\hline $\mathrm{PC}+1 \%$ biochar & 3,978 & 14.58 & 14.58 & 115.20 & 451.98 \\
\hline
\end{tabular}

"AD; aerobic digestate, $\mathrm{CC}$; cow compost, $\mathrm{PC}$; pig compost. ${ }^{* *} 1 \mathrm{~kg} \mathrm{C}=3.664 \mathrm{~kg} \mathrm{CO} \mathrm{CO}_{2}$.

Table 4. Responses of plant growth and yield to different organic composts and cooperated with biochar for corn cultivation.

\begin{tabular}{|c|c|c|c|}
\hline Treatments $^{*}$ & Plant height $(\mathrm{cm})$ & Fresh yield $\left(\mathrm{kg} \cdot \mathrm{ha}^{-1}\right)$ & Fresh biomass weight $\left(\mathrm{kg} \cdot \mathrm{ha}^{-1}\right)$ \\
\hline $\mathrm{AD}$ & $177.6 \pm 7.3$ & $12,226 \pm 245$ & $59,858 \pm 3857$ \\
\hline $\mathrm{CC}$ & $184.9 \pm 4.4$ & $12,915 \pm 201$ & $64,259 \pm 6072$ \\
\hline $\mathrm{PC}$ & $184.2 \pm 2.1$ & $12,599 \pm 269$ & $66,421 \pm 9899$ \\
\hline PC $+1 \%$ Biochar & $188 \pm 2.4$ & $12,484 \pm 263$ & $68067 \pm 1475$ \\
\hline
\end{tabular}

${ }^{*} \mathrm{AD}$; aerobic digestate, CC; cow compost, PC; pig compost. 


\section{Acknowledgements}

We thank National Institute of Agricultural Science, Rural Development Administration beyond Research Program of Science \& Technology Development for funding the study (Project No. PJ 010920).

\section{References}

[1] Koocheki, A. and Nassiri Mahallati, M. (2008) Impact of Climate Change and $\mathrm{CO}_{2}$ Concentration on Wheat Yield in Iran and Adaptation Strategies. Iran Journal of Field Crops Research, 6, 139-153.

[2] Koocheki, A., Nassiri, M., Kamali, G.A. and Shahandeh, H. (2006a) Potential Impact of Climate Change on AgroMeteorological Indicators in Iran. Arid Land Research and Management, 20, 245-259. http://dx.doi.org/10.1080/15324980600705768

[3] Koocheki, A., Nassiri, M., Soltani, A., Sharifi, H. and Ghorbani, R. (2006b) Effects of Climate Change on Growth Criteria and Yield of Sunflower and Chickpea Crops in Iran. Climate Research, 30, 247-253. http://dx.doi.org/10.3354/cr030247

[4] IPCC (1996) Intergovernmental Panel on Climate Change. Climate Change 1995: The Science of Climate Change. Cambridge University Press, Cambridge.

[5] IPCC (1999) Intergovernmental Panel on Climate Change, Data Distribution Center. CD-ROM Version 1.0 Providing Climate Change and Related Scenarios for Impact Assessments, Climatic Research Unit, University of East Anglia, Norwich.

[6] Lal, L. (2002) Soil Carbon Dynamics in Cropland and Rangeland. Environmental Pollution, 116, 353-362. http://dx.doi.org/10.1016/S0269-7491(01)00211-1

[7] Atkinson, C.J., Fitzgerald, J.D. and Hipps, N.A. (2010) Potential Mechanisms for Achieving Agricultural Benefits from Biochar Application to Temperate Soils: A Review. Plant and Soil, 337, 1-18. http://dx.doi.org/10.1007/s11104-010-0464-5

[8] Laird, A.D. (2008) The Charcoal Vision: A Win-Win-Win Scenario for Simultaneously Producing Bioenergy, Permanently Sequestering Carbon, While Improving Soil and Water Quality. Agronomy Journal, 100, 178-184. http://dx.doi.org/10.2134/agrojnl2007.0161

[9] MIFAFF (2010) Annual Statistics in Food, Agriculture, Fisheries and Forestry in 2009. Korean Ministry for Food, Agriculture, Fisheries and Forestry.

[10] Hammes, K. and Schmidt, M. (2009) Changes in Biochar in Soil. In: Lemann, J. and Joseph, S., Eds., Biochar for Environmental Management, Earthscan, Location, 169-182.

[11] Lehmann, J., Kern, D.C., Glaser, B. and Woods, W.I. (Eds.) (2004) Management. Kluwer Academic Publishers, New York.

[12] Lehmann, J., Rilling, M.C., Thies, J., Masiello, C.A., Hockaday, W.C. and Crowley, D. (2011) Biochar Effects on Soil Biota: A Review. Soil Biology and Biochemistry, 43, 1812-1836. http://dx.doi.org/10.1016/j.soilbio.2011.04.022

[13] Kimble, J.M., Lal, R. and Follett, R.R. (2002) Agricultural Practices and Policy Options for Carbon Sequestration: What We Know and Where We Need to Go. In: Kimble, J.M., Lal, R. and Follet, R.F., Eds., Agricultural Practices and Policies for Carbon Sequestration in Soil, Lewis Publishers, New York, 512.

[14] Batjes, N.H. (1996) Total Carbon and Nitrogen in the Soils of the World. European Journal of Soil Science, 47, 151163. http://dx.doi.org/10.1111/j.1365-2389.1996.tb01386.x

[15] Chicago Climate Exchange (CCX) (2008) December 2008 Market Summary. CCS Market Report, 5, 1-4. http://www.chicagoclimatex.com/docs/publications/CCS_carbonmkt_V5_i12_dec2008.pdf

[16] European Climate Exchange (ECX) (2008) Certified Emission Reduction Futures Contracts-2008 Historic Data. http://www.ecx.eu/CRE-Futures

[17] Shin, J.D., Kim, S.I., Park, W.K., Choi, Y.S., Hong, S.G. and Park, S.W. (2014) Carbon Sequestration in Soil Cooperated with Organic Composts and Biochar during Corn (Zea mays) Cultivation. Journal of Agricultural Chemistry and Environment, 3, 151-155.

[18] Shin, J.D., Choi, Y.S., Kim, H. and Shin, T. (2015) Predicting Greenhouse Gas Reduction and Profit Analysis by Soil Carbon Sequestration in Corn Field with Different Application Rates of Biochar during Cultivation Periods. Conference Proceeding of APESEET 2015, Seoul, 2-5 July 2015, 241-246.

[19] Kuzyakov, Y., Subbotina, I., Chen, H., Bogomolova, I. and Xu, X. (2009) Black Carbon Decomposition and Incorporation into Soil Microbial Biomass Estimated ${ }^{14} \mathrm{C}$ Labeling. Soil Biology and Biochemistry, 41, 210-219. http://dx.doi.org/10.1016/j.soilbio.2008.10.016 


\section{Submit or recommend next manuscript to SCIRP and we will provide best service for you:}

Accepting pre-submission inquiries through Email, Facebook, LinkedIn, Twitter, etc.

A wide selection of journals (inclusive of 9 subjects, more than 200 journals)

Providing 24-hour high-quality service

User-friendly online submission system

Fair and swift peer-review system

Efficient typesetting and proofreading procedure

Display of the result of downloads and visits, as well as the number of cited articles

Maximum dissemination of your research work

Submit your manuscript at: http://papersubmission.scirp.org/ 